\title{
PENGEMBANGAN INDUSTRI MEBEL SEBAGAI UPAYA UNTUK MENINGKATKAN MOTIVASI BERPRESTASI MASYARAKAT PASEH KEBUPATEN SUMEDANG
}

\author{
Oleh: Moch. Eryk Kamsori*)
}

\begin{abstract}
Abstrak
Pembangunan industri merupakan bagian usaha jangka panjang untuk merubah struktur ekonomi yang kokoh dan seimbang antara pertanian dan Industri. Pembangunan industri memberikan corak baru bagi kehidupan masyarakat. Dengan adanya industri masyarakat dapat lebih maju dan berkembang. Status proses perubahan kearah lebih maju harus ditunjang oleh sikap dan perilaku masyarakat untuk menerima perubahan-perubahan yang terjadi. Untuk itu, sumber daya manusia yang berkualitas perlu dipersiapkan.

Umumnya etos kerja yang dimiliki masyarakat Indonesia sangat kurang, apalagi didaerah pedesaan yang hanya mengandalkan pada sumber daya alam yang ada. Masyarakat pedesaan mempunyai motivasi berprestasi yang sangat minim, mereka hanya mengerjakan apa yang sudah jadi kebiasaan turun temurun dari orang tua mereka.

Kondisi di atas terjadi juga terhadap masyarakat di Kecamatan Paseh, Kabupaten Sumedang. Namun begitu pemerintah setempat tidak tinggal diam dan berusaha untuk mengembangkan potensi ekonomi utama yaitu industri kerajinan mebel seperti lemari, kursi, meja dan macam-macam perabot rumah tangga lainnya. Dengan demikian diharapkan masyarakat Paseh Kabupaten Sumedang untuk berkembang. Kata kunci: motivasi, prestasi kerja.
\end{abstract}

*) Erik Kamsori, S.Pd adalah dosen Jurusan Pendidikan Sejarah FPIPS UPI. 


\section{Pendahuluan}

Seperti kita ketahui bahwa segala sesuatu yang terjadi dimuka bumi ini pasti ada sebabnya. Begitu juga dengan pembangunan industri dilatarbelakangi oleh beberapa hal. Pembangunan industri ditujukan sebagai upaya untuk memenuhi kebutuhan masyarakat yang semakin maju sehingga tercipta masyarakat adil dan makmur. Selain itu dengan melakukan pembangunan industri tersebut dapat meningkat pendapatan ekonomi rakyat, menghasilkan suatu teknologi yang canggih dan tepat guna serta mengikuti serta masyarakat secara aktif terlibat dalam kegiatan industri tersebut. Seperti yang digariskan dalam UndangUndang Republik Indonesia nomor 5 tahun 1984 tentang perindustrian, pembangunan industri di Indonesia memiliki tujuan sebagai berikut :

1) Meningkatkan kemakmuran dan kesejahteraan rakyat secara adil dan erak dengan manfaatkan sumber daya alam, dan atau hasil budidaya serta dengan memperhatikan keseimbangan dan kelestarian lingkungan hidup.

2) Meningkatkan pertumbuhan ekonomi secara bertahap, mengubah struktur perekonomian kea rah yang lebih baik, maju, sehat dan lebih seimbang sebagai upaya untuk mewujudkan dasar yang lebih luas bagi pertumbuhan industri pada khususnya.

3) Meningkatkan kemampuan dan penguasaan serta mendorong terciptanya teknologi yang tepat guna dan menumbuhkan kepercayaan terhadap kemampuan dunia usaha nasional.

4) Meningkatkan keikutsertaan masyarakat dan kemampuan golongan ekonomi lemah termasuk pengrjin agar berperan serta aktif dalam pembangunan industri.

5) Memperluas dan meratakan kesempatan kerja dan kesempatan berusaha serta meningkatkan peranan koperasi industri

6) Meningkatkan penerimaan devisa melalui peningkatan ekspor hasil produksi nasional yang bermutum disamping penghematan devisa melalui pengutamaan pemakaian hasil produksi dalam negeri guna mengurangi ketergantungan pada luar negeri. 
7) Pengembangan pusat-pusat pertumbuhan industri yang menunjang pembangunan daerah dalam rangka perwujudan wawasan nusantara

8) Menunjang dan memperkuat stabilitas nasional yang dinamis dalam rangka memperkokoh ketahanan nasional.

\section{Metodologi Penelitian}

Metode penelitian yang digunakan dalam penelitian ini adalah menggunakan pendekatan kualitatif. Pendekatan kualitatif ini dicirikan oleh tujuan penelitian yang berupaya untuk memahami gejala-gejala yang sedemikian rupa dan karena gejala-gejala tersebut tidak memungkinkan untuk diukur secara tepat. Dalam penelitian ini penulis mempergunakan metode deskriptif-analitik. Hal ini berdasarkan pada permasalahan yang penulis teliti yaitu tentanmg masalah factual sekarang. Penelitian deskriptif berusaha mendeskripsilan dan menginterprestasikan apa yang ada (bias mengenai kondisi atau hubungan yang ada, pendapat yang sedang tumbuh, proses sedang berlangsung, akibat atau efek yang terjadi, atau kecenderungan yang sedang angket, wawancara atau observasi.

Dalam penelitian ini juga penulis menggunakan beberapa teknik pengumpulan data sebagai berikut :

a) Observasi atau pengamatan langsung penulis di lapangan. Adapaun tujuan tehnik observasi ini adalah untuk mengamati secara langsung tentang kegiatan atau proses kehidupan sehari-hari dari para pekerja pengrajin meubel di Kecamatan Paseh Kabupaten Sumedang

b) Wawancara yaitu percakapan denga bertatap muka dengan tujuan memperoleh informasi factual untuk menaksir dan menilai kepribadian individu atau untuk tujuan penyuluhan dan konseling.

c) Studi literature atau kepustakaan dengan tujuan untuk mendapatkan konsep-konsep dan teori-teori yang ada hubungannya dnegan masalah yang diteliti dan dapat dijadikan sebagai landasan pemikiran dalam penulisan ini sehingga diperoleh keterkaitan antara tujuan. 


\section{Pengertian Industri}

Industri merupakan salah satu kegiatan ekonomi manusia yang penting. Ia menghasilkan berbagai kebutuhan hidup manusia dari mulai makanan, minuman pakaian dan perlengapan rumah tangga sampai perumahan dan kebutuhan lainnya. Selain menghasilkan keperluan hidup, industri juga merupakan nafkah sebagian penduduk (Idris Abdurahmat, 1983:1)

Kata industri berasal dari bahasa Latin "Industria" yang secara sederhana dapat diartikan sebagai buruh atau penggunaan tenaga kerja. Biro Pusat Statistik (BPS) mendefinisikan bahwa industri sebagai suatu kegiatan pengubahan barang dasar menjadi barang jadi atau setengah jadi atau dari yang kurang nilainya menjadi barang yang lebih tinggi nilainya dengan maksud untuk dijual.

Sejalan dengan pengertian dari BPS tersebut, dalam UndangUndang Republik Indonesia nomor 5 tahun 1984 tentang perindustrian bahwa yang dimaksud dengan industri adalah kegiatan ekonomi yang mengolah bahan mentah, bahan baku, barang setengah jadi, dan atau bahan jadi menjadi barang dengan nilai yang lebih tinggi untuk penggunanya, termasuk kegiatan rancang bangun dan perekayasaan.

Sementara itu definisi industri menurut Sandi (1988:48) bahwa, "Industri adalah usaha untuk memproduksi barang-barang jadi dan bahan baku atau bahan mentah melalui suatu proses barang-barang itu bias diperoleh dengan harga satuan yang serendah mungkin, tetapi tetap dengan mutu setinggi mungkin.

Istilah industri mempunyai dua pengertian yaitu (1) pengertian dalam arti luas, (2) pengertian dalamarti sempit. Nursid Sumaatmadja (1988:179) mengemukakan pengertian industri secara luas sebagai kegiatan manusia memanfaatkan sumber daya, sedangkan dalam arti sempit industri adalah suatu kegiatan ekonomi yang mengolah bahan mentah menjadi barang jadi atau setengah jadi (manufacturing industry).

Sedangkan Idris Abrurachmat dalam bukunya yang berjudul Geografi Industry (1983:1-2) mengatakan bahwa, Pengertian industri 
dalam arti luas adalah berbagai macam kegiatan ekonomi baik kegiatan sector primer, sekunder maupun tertier. Pengertian industri secara sempit ialah pengertian yang berkenaan dengan istilah manufactur, yaitu segala usaha atau kegiatan yang sifatnya mengubah dan mengolah bahan mentah setengah jadi atau barang jadi”

Industri primer adalah industri yang mengolah bahan-bahan mentah hasil produksi sector primer baik dari pertanian, peternakan, perikanan, kehutanan, maupun pertambangan. Selanjutnya, yang dimaksud dengan industri sekunder adalah industri-industri yang mengolah lebih lanjut hasil indutri lainnya (industri primer), yang bahan bakunya adalah barang jadi atau barang setengah jadi termasuk kedalamnya adalah industri mibil, meubeul, pakaian jadi dan industri makanan. Pengertian industri tertier yaitu kegiatan ekonomi yang tidak berhubungan dengan bahan mentah atau barang-barang setengah jadi tetapi bergerak dibidang jasa misalnya perbankan, pariwisata, dan perdagagngan (Idris Abrurachmat, 1983:16).

\section{Pengaruh Pembangunan Industri Terhadap Kehidupan Ekonomi Masyarakat}

Besarnya jumlagh penduduk pada golongan usia muda, tingkat ekonomi yang rendah dan terbatasnya lapangan pekerjaan, merupakan masalah utama yang selalu timbul di kawasan Negara berkembang. Keadaan ini nampak dari kehidupan masyarakat di daerah perkotaan maupun pedesaan.

Pembangunan industri yang dilakukan memberikan pengaruh yang sangat besar terhadap kehidupan masyarakatnya, terutama dalam bidang ekonomi. Dengan adanya industri tersebut terjadi perubahan dalam hal lapangan pekerjaan adalah semua kegiatan yang menghasilkan uang sebagai penopang ekonomi rumah tangga. Dengan adanya industri tersebut terjadi perubahan dalam hal lapangan pekerjaan bagi masyarakat. Yang dimaksud dengan lapangan pekerjaan adalah semua kegiatan yang menghasilkan uang sebagai penopang ekonomi rumah 
tangga. Sedangkan dalam permasalahan ini faktor tenaga kerja, tidak dapat dikesampingkan. Adapun yang dimaksud dengan tenaga kerja (Working Age) adalah penduduk yang berumur 10 tahun ke atas. (Hananto Sigit, 1982:14).

Dengan dibangunnya industri memberikan kesempatan yang luas dan terbuka kepada masyarakat untuk bekerja di industri tersebut, baik yang langsung diakibatkan oleh industri sendiri, misalnya dengan dibukanya lowongan pekerjaan baru yang akan dipekerjakan sebagai karyawan di industri tersebut, dan diakibatkan lain yang bersifat tidak langsung misalnya: kesempatan dalam usaha-usaha ekonomi bebas. Usaha-usaha ekonomi bebas merupakan usaha yang langsung memenuhi kebutuhan industri dan yang tidak langsung memenuhi kebutuhan industri.

Dengan terbukanya kesempatan masyarakat untuk bekerja di industri tersebut membawa dampak yang baik bagi kehidupan masyarakat. Bagaimanapun juga kehidupan sebagai karyawan pabrik atau industri adalah terjamin. Disini mereka berharap memperoleh penghasilan yang relatif lebih stabil dan tetap jumlahnya. Kemungkinan memperoleh kaminan hari tua baik berupa pesangon atau pension, adanya perlindungan kerja yang diatur perburuhan dan berbagai kontribusi soal lainnya. Bagi mereka, dengan bekerja di industri tersebut dapat memberikan penghasilan dalam kehidupan sehari-hari. Penghasilan yang mereka peroleh dari bekerja dapat membantu masyarakat untuk menutupi kebutuhan sehari-hari.

Oleh sebab itu, dengan munculnya kesempatan untuk bekerja menjadi karyawan di industri, maka kesempatan baik itu tidak mereka sia-siakan. Begitu bervariasinya bidang pekerjaan di pabrik, sehingga banyak menampung tenaga tanpa persyaratan yang begitu berat, baik dari segi keterampilan maupun ijasah formal. Kesempatan untuk bekerja di industri tersebut bukan hanya untuk laki-laki saja tetapi perempuan juga memiliki kesempatan yang besar untuk bekerja di industri tersebut. Kesempatan untuk menjadi karyawan bagi perempuan sangat 
menguntungkan mereka, sebab selama bekerja di industri tersebut tidak dibatasi bagi mereka, yang sudah menikan dan sebagainya. Sehingga pada akhitnya banyak juga diantara perempuan atau ibu rumah tangga yang kemudian memanfaatkan kesempatan it masuk menjadi karyawan di industri tersebut.

Hakikat pembangunan nasional adalah manusia seutuhnya dan pembangunan masyarakat Indonesia. Disamping itu pembangunan nasional bertujuan untukmewujudkan suatu masyarakat adil dan makmur yang merata material dan spiritual berdasarkan Pancasila di dalam wadah Negara Kesatuan Republik Indonesia yang meredeka dan berdaulat (Moh. Soejadi dkk, 1987:252)

Istilah pembangunan dipakai dalam pengertian yang lebih luas dari pada istilah moderenisasi. Di Indonesia mederenisasi terutama ditekankan pada seltor pertanian disamping sektor lainnya. Pada dasarnya pengertian moderenisasi mencakup suatu transformasi total kehidupan bersama yang tradisional atau pra modern dalam arti teknologi serta organisasi sosial, kearah pola-pola ekonomis dan politis yang menjadi cirri Negara-negara barat yang stabil.

Adapun yang menjadi persyaratan dari moderenisasi itu menurut Max Webber dan David Mc. Clelland lebih menunjukan pentingnya peran kewajiban dalam moderenisasi tersebut. Keinginan untuk mencapai hasil kerja yang lebih baik, keberanian mengambil resiko dan keinginan melihat keberhasilan yang nyata, adalah bagian dari jiwa kewiswastaan yang diperlukan dalam proses moderenisasi (Awan Mutakin, 1999:23).

Selanjutnya mengenai motivasi berprestasi David Mc. Clelland menyatakan pendapatnya yang paling adalah keinginan seseorang untuk terus maju dan melihat perkembangan sejarah suatu bangsa yang maju mundur atau pernah mengalami kejayaan dan mengalami kemandegan bahkan kehancuran kemudian dihubungkan dengan perkembangan ekonominya. Menurutnya pula kemajuan suatu bangsa tergantung dari kemajuan bangsa itu sendiri untuk maju yang dilatarbelakangi oleh ketidak puasan dengan hasil yang dicapainya atau keinginan untuk terus 
berprestasi. Ketidakpuasan dengan hasil yang dicapai dari suatu bangsa dipersempit lagi menjadi keinginan individu untuk mendapatkan yang lebih baik dari sebelumnya yang terus tertanam dan sulit dilepaskan, seakan-akan sebagai virus yang sudah menetap dalam tubuh seseorang. Karena itu, Mc. Clelland menyebut sebagai virus mental yang disebut Need for Achievement (n-Ach).

Selanjutnya Mc. Clelland (tanpa tahun : 2) mengemukakan “.....Virus mental, yakni cara berpikir pada diri seseorang, cenderung untuk menyebabkan orang itu bertingkah laku secara giat ....”, untuk itulah virus ini ditemukan pada suatu macam pikiran yang berhubungan dengan melakukan sesuatu dengan baik ataupun melakukan sesuatu dengan baik daripada yang pernah dibuat sebelumnya. Motivasi untuk mencapai prestasi dimulai dari pendidikan terhadap anak dengan cara memberikan unsure-unsur yang dapat membangkitkan semangat dan motivasi berprestasi setinggi mungkin.

Keberhasilan suatu Negara dalam bidang pembangunan ekonomi dengan kebutuha untuk mencapai pretasi warganya berkolerasi positif, terutama di awal pertumbuhan ekonomi Negara bersangkutan yang ditandai dengan munculnya semangat wiraswasta atau wirausaha dari warga masyarakat yang bergerak di bidang ekonomi sebagai pengusaha kecil, pedagang kecil atau sebagai pengrajin mereka ini tidak senang dengan hasil yang dicapai walaupun hasil tersebut sudah dapat menghidupi usahanya, hingga dapat menyerap banyak tenaga kerja bahkan hasilnya bisa untuk diekspor ke berbagai Negara. Wiraswasta muncul tidak langsung menjadi pengusaha besar melainkan dimulai dari usaha kecil yang berkembang menjadi usaha besar. Dengan demikian, adanya kebutuhan untuk mencapai pretasi dengan adanya virus mental yang bernama $n$-Ach tidak akan cukup tanpa adanya dorongan lain yang mendukung pembangunan, karena Mc. Clelland sendiri mengemukakan bahwa n-Ach bukan satu-satunua factor modernisasi. Perlu dikatahui pula bahwa kemajuan suatu masyarakat selain dari individu yang menginginkan perubahan untuk lebih baik, juga lingkungan social 
dimana individu itu berada akan turut menentukan keberhasilan adanya virus n-Ach. Lebih jauh lagi yang tidak mendukung timbulkan n-Ach adalah system nilai yang berlaku di masyarakat, system kekuasaan, kesempatan untuk berkarya, pengakuan masyarakat akan hasil.

\section{Hasil Penelitian Dan Pembahasan}

Dalam penelitian ini penulis mengambil lokasi di Kecamatan Paseh Kabupaten Sumedang. Secara geografis Kecamatan Paseh ini merupakan daerah pertanian dan dilewati oleh jalan provinsi. Kecamatan Paseh mempunyai ketinggian 200-600 meter di atas permukaan laut, curah hujannya rata-rata $2160 \mathrm{~mm}$ per tahuan. Sedangkan keadaan suhunya berkisar antara 23-30 C

Kondisi sosial dan ekonomi di Kecamatan Paseh rata-rata sebagai petani dan pengrajin meubel, hal ini sesuai dengan kondisi geografis yang merupakan daerah pertanian, Kecamatan Paseh juga dikenal sebagai Kota Mebel. Banyak barang-barang furniture seperti kursi, lemari dan parabot rumah tangga lainnya yang dihasilkan oleh para pengrajin mebel di Kecamatan Paseh. Mata pencaharian sebagai pengrajin merupakan mata pencaharian yang bias dikatakan sebagai tradisi Karena di turunkan dari generasi ke generasi.

Sosial kemasyarakatannya terasa masih kental tradisi dan kekerabatannya. Hubungan antar anggota masyarakat masih terlihat, apalagi pada saat acara-acara keagamaan, mengingat di Kecamatan Paseh ini masyarakatnya $100 \%$ menganut agama Islam. Nilai-nilai gotong royong pun senantiasa dipelihara oleh Masyarakat.

Sampai saat ini jumlah industri mebel yang ada di Kecamatan Paseh sekitar 125 perusahaan dan dapat menyerap tenaga kerja kurang lebih 4589 tenaga kerja yang 99,5\% adalah laki-laki. Yang menjadi tenaga kerjanya adalah masyarakat setempat dan juga masih keluarga. Usia tenaga kerjaadalah usia produktif yang kebanyakan adalah tamatan SD dan SMP dan tidak melanjutkan sekolah. Daerah pemasaran dari hasil produk industri mebel ini selain di Kabupaten Sumedang sendiri juga 
antar kabupaten seperti Jakarta, bekasim Subang, bandung bahkan sempat keluar negeri, yaitu Arab Saudi tapi pemasaran ke Arab Saudi ini tidak berlenjut disebabkan modal dan pengetahuan mereka tentang halhal yang berkaitan dengan ekspor/import sangat terbatas. Untuk itu mereka lebih memfokuskan pada daerah pemasaran yang telah ada.

Jumlah industri mebel ini semakin meningkat karena para pekerja yang dulnya jadi pekerja salah satu perusahaan, karena pengalaman dan kesempatan mereka akhirnya mendirikan sendiri perusahaan mebelnya dan merekrut tenaga kerja baru. Meskipun para pekerja ini kebanyakan hanya tamatan SD dan SMP, tapi hal ini tidak menjadi hambatan bagi mereka untuk terus belajar, selain itu mereka juga tinggal dilingkungan sekitar tempat mereka bekerja. Selain itu degan seringnya mereka pergi keluar kota memasarkan hasil produksinya memberikan pengalaman dan pengetahuan yang baru bagi mereka. Dengan mengembangkan perusahaan mebel secara langsung telah membuka kesempatan bagi masyarakat dan para pemuda putus sekolah ini lebih memiliki untuk jadi pengrajin dari pada bertani. Pengetahuan dan pengalaman baru yang didapat para pengrajin setelah pulang dari luar kota, telah memberi motivasi bagi mereka untuk menciptakan hal-hal baru dan terus berkreasi untuk memproduksi barang-barang urniture agar tetap digemari oleh pasar serta tidak ketinggalan zaman. Mereka menjadi manusia yang tidak pernah puas dengan hasil yang telah mereka dapatkan sekarang.

Motivasi mereka untuk terus berpartisipasi ini ditunjang dengan adanya kesempatan bagi mereka untuk menyalurkan kreatifitas mereka yaitu dengan adanya perusahaan-perusahaan mebel baru yang merekrut mereka sebagai tenaga kerja. Yang kemudian lama-kelamaan mereka juga membuka perusahaan sendiri meskipun secara kecil-kecilan karena modal yang terbatas. Melihat dampak positif yang disebabkan pengembangan sector industri mebel, mendapat dukungan dari pemerintah setempat. Pemerintah mendukung pengembangan sector industri ini selain sebagai upaya untuk meningkatkan kesejahteraan 
masyarakat Paseh juga dengan begitu dapat mempertahankan Kecamatan paseh sebagai Kota Mebel di Kabupaten Sumedang .

\section{Penutup}

Pembangunan industri yang dilakukan oleh pemerintah bukan tanpa tujuan yang pasti. Kegiatan pembangunan industri ini diarahkan oleh pemerintah untuk meningkatkan taraf kehidupan masyarakat. Dengan adanya industri maka masyarakat mempuberkompetensi untuk mengembangkan kemampuannya guna mememnuhi kebutuhan hidupnya. Dalam hal terbukti, bahwa dengan pembangunan industri telah memberikan kesempatan kepada masyarakat untuk mendapatkan lapangan pekerjaan. Kesempatan bekerja bagi masyarakat semakin terbuka lebar. Dengan segenap potensi masyarakat dapat memenuhi kebutuhan ekonomi keluarganya.

Pembangunan industri juga telah memberikan kesempatan kepada masyarakat yang berada disekitar tempat industri untuk membuka lapangan usaha. Lapangan usaha yang mereka lakukan adalah dengan membuka tempat tinggalnya sebagai kost atau tempat sewa bagi karyawan yang bekerja di industri tersebut, dari usaha ini masyarakat memperoleh penghasilan. Sehingga kegiatan ini menjadi kegiatan bisnis masyarakat disektar industri.

Dengan demikian adanya pembangunan industri ini memberikan dampak positif bagi pengembangan ekonomi masyarakat. Sedangkan dampat negatifnya adalah munculnya masalah urbanisasi. Urbanisasi muncul karena banyaknya masyarakat desa yang mencari lapangan pekerjaan di kota. Apalagi setelah dibangun industri-industri tersebut.

Era moderenisasi yang menekankan pada sector industri, telah terjadi juga pada sector industri modern yang ruang lingkupnya masih sangat terbatas dan ada di daerah seperti Kecamatan Paseh Kabupaten Sumedang. Ketekunan yang dimiliki para pengarjin kecil ini telah membawa mereka untuk mengembagkan diri mereka sebdiri dan juga demi kesejahteraan hidup dirinya sendiri serta keluarganya. Motivasi 
berprestasi yang telah dimiliki dapat ditingkatkan dengan adanya sarana dan kesempatan bagi mereka yaitu perusahaannya itu sendiri yang berkembang. Namun begitu setelah penulis lakukan pengamatan dilapangan, penulis menemukan beberapa hal yang datangnya dari pihak pemerintah dan pihak-pihak yang mempunyai modal agar para pengrajin mebel ini dapat mengembangkan usahanya. Selain itu pengarahan dan pelantikan terhadap pengrajin perlu juga untuk dilakukan kepada para pengrajin kecil ini terutama tentang manajemen perusahaan yang baik sehingga diharapkan industri mebel ini terus berkembang dan lebih professional.

\section{Daftar Pustaka}

Awan Mutakin. 2002. Dinamika Kehidupan Masyarakat Perkotaan. Bandung: Anggita Pustaka Mandiri. . 1997/1998. Studi Masyarakat Indonesia. Depdikbud.

R. Bintarto. 1993. Urbanisasi dan Permasalahannya. Yogyakarta: Ghalia Indonesia.

Helmi Aswan, dkk. 1994/1995. Dampak Pembangunan Industri Terhadap Kehidupan Budaya Masyarakat Setempat di Jawa Timur. Depdikbud.

Sandi. 1986. Geografi Regional Indonesia. Jakarta : Viprasi.

Siti Maria, dkk. 1997/1998. Pergeseran intreprestasi Terhadap Nilainilai Keagamaan Di "Kawasan Industri" KotagedeYogyakarta.Jakarta : Depdikbud.

Pudjiwati Sajogyo. 1995. Sosiologi Pembangunan. Jakarta. Fakultas Pasca Sarjana IKIP Jakarta dan BKKBN.

Moch Soerjadi, dkk (ed). 1987. Lingkungan : Sumber Daya Alam dan Kependudukan Dalam Pembangunan. Jakarta. UI Press. 